||IIIIIIIIIIIIIIIIIIIIIIIIIII

速 報

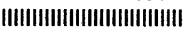

\title{
服装の評価に及ぼす提示試料の背景の影響
}

\author{
山本昌子*，山田千賀子**，黒田喜久枝 ${ }^{* * *}$ ，太田健一****
}

\section{Influence of Stimulus Background on Evaluation of Clothing}

(Received April 9, 1997)

(Accepted by Publication Sept. 9, 1997)

\section{1. 緒 言}

ある人がある場面で着ている衣服が評価されると き，その衣服の色と形態が主としてその評価に影響 するが，その着用者の特性，着用場面む複合してそ の評価に作用している。このため，服装評価におい ては，衣服の特性ととあに衣服の特性之着用者の特 性による相互作用，衣服の特性と着用場面の相互作 用による影響あ検討する必要がある.

前者の相互作用は一般に「似合う／似合わない」 という観点から評価されており，衣服の色と着用者 の肌色や髪の色，衣服の形態之着用者の髮型や顔型 との適合などについて検討されている ${ }^{1}$. 後者の相 互作用である衣服の特性と着用場面の相互作用につ いては，これまでほとんど注目されず，山本らによ る検討以外に報告は見当たらない，山本らは衣服を 構成する色, 形態, 着用場面を独立変数とし，これ らの変数が単独あるいは複合して服装評価にどのよ うに影響するかを測定している2).

本研究では, 服装評価に及ぼす衣服と着用場面の 影響および衣服と着用場面の相互作用の影響を検討 した。試料として用いた衣服はスーツからパンッま で数種を選定し，これらの衣服が着用されている状 態の服装写真の背景を変えたものを提示試料として 用いた．背景を変えることによって服装の評価者に 対して暗默理に着用場面と対応させてその服装を評 価してもらう方法を採用した。

\section{2. 方 法}

\section{1 提示試料}

服装評価に用いた服装は, 学生達がよく読んでい るファッション雑誌（JJ, 11. 1995, Soen, 11, 1995, 'ef，11，1995） や通信販売のカタログ（ニッセン 1995 秋）から日常着られるようなものを服種，デ ザイン，色，柄，などが偏らないように予備実験に よって 7 種類の服装を選定し，カラースキャナーを 用いて入力した。これらの画像には服装と背景が含 まれているので，まず服装の領域のみを抽出して背 景から分離し, 基準となる無背景の画像を作成し た. 服装の種類を表 1 に示す.

背景の選定には，基準となる無背景と日々の生活 環境の中から異なる「街中」,「野外」「室内」の場 面をそれぞれ 1 点ずつ撮影および雑誌から選定し, それを図 1 に示す.

\section{提示試料の作成}

背景画像の任意な場所に服装のみに分離した画像 を貼りつけるが，貼りつけた服装と背景は，それぞ れ別の場所や条件のもとで撮影されたあのであるか ら光学的条件に統一性がないため,このままの画像 では場面としての違和感が大きく，提示試料として は適さない，そこで違和感を軽減するために服装領 域の輪郭部に近隣する領域画素の画素値をランダム に入れ替えて輪郭をぼかし，周囲となじませるよう に違和感を減少させて合成画像を作成した。試料は

Masako Yamamoto* Chikako Yamada** Kikue Kuroda*** and Ken'ichi Outa****

*Member, 夙川学院短期大学, Shukugawagakuin Junior College, **Member, 池坊短期大学, Ikenobo Junior College,

$* * *$ Member, 近畿大学豊岡短期大学, Kinki University Toyooka Junior College, **** Member, 姫路工業大学, Faculty of Engineering, Himeji Institute of Technology 
Table 1 Test Outfits

\begin{tabular}{|c|c|c|}
\hline Sample No. & Feature & Source \\
\hline Clothing typel & $\begin{array}{l}\text { Beige tailored-collar suit } \\
\text { (dark brown upper collar,mini-skirt) }\end{array}$ & ニッセ（1996） \\
\hline Clothing type 2 & Black tailored blazer with beige pants & JJ (1995) \\
\hline Clothing type 3 & Pink Chanel-style suit (mini-skirt) & JJ (1995) \\
\hline Clothing type 4 & $\begin{array}{l}\text { Yellow pattern on red around tailored-collar two-piece } \\
\text { (wraparound mini-skirt) }\end{array}$ & ニッセ（1996) \\
\hline Clothing type 5 & Grey turtleneck sweater and grey mini-skirt & e'f (1995) \\
\hline Clothing type6 & $\begin{array}{l}\text { Red jacket (brown shirtlike collar and cuffs) and brown } \\
\text { diagonal checks on red ground mini-skirt }\end{array}$ & JJ (1995) \\
\hline Clothing type7 & Light purple long knit ensemble (dress and cardigan) & So-en (1995) \\
\hline
\end{tabular}
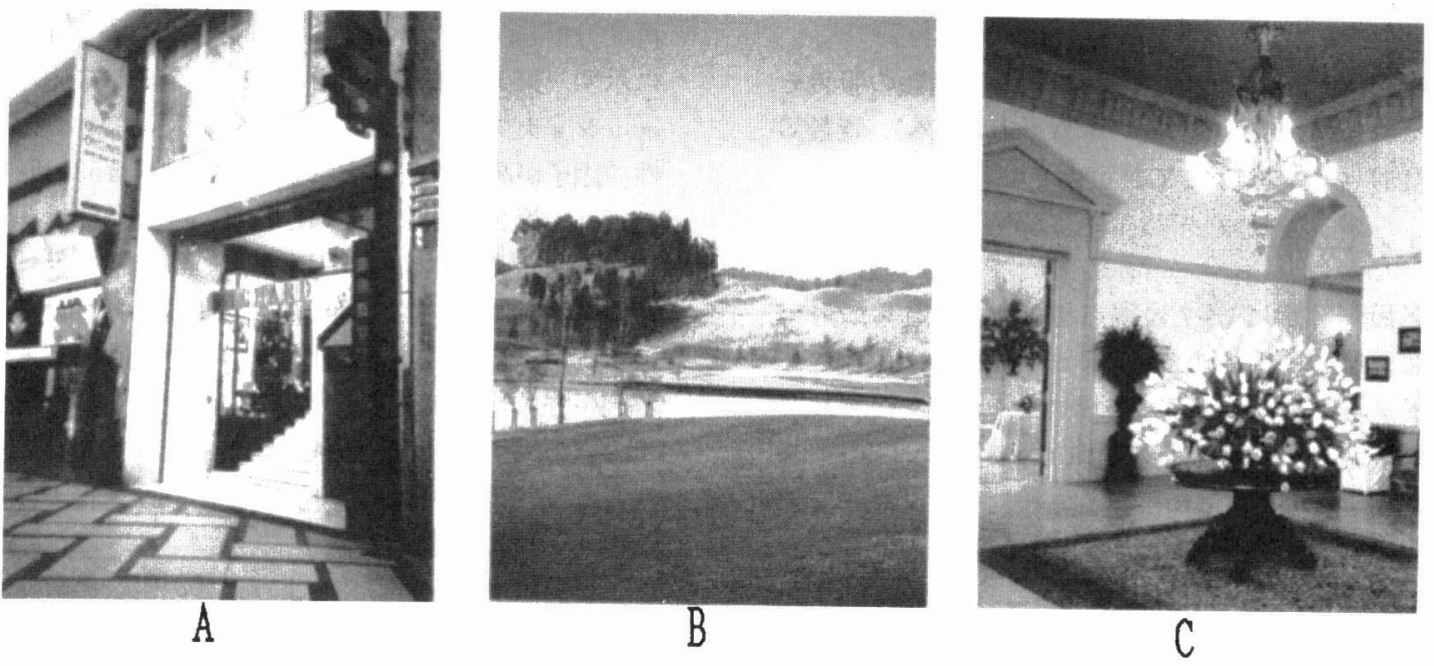

Fig. 1 Three Types of Background

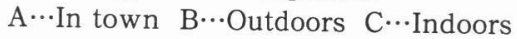

無背景の服装 7 種類, 背景 A 「街中」, 背景 B 「野 外」, 背景 C「室内」と 7 種類の服装それぞれとの合 成画像の 28 種類の OHP フィルムを作成した，室内 における服装 6 の合成画像例を図 2 に示す.

\section{2 評定尺度}

$\mathrm{SD}$ 法によって服装の評定を行うのに適当と思わ れる形容詞は，これまで多くの SD 法の結果の因子 分析によって力量性, 評価性, 活動性の 3 因子が見 出されているので3)それらの因子を含む尺度を予備 実験によって, 派手な/地味な, 大胆な/繊細な,
にぎやかな/落ち着いた, 個性的な/平凡な, すっ きりした/ごてごてした，ファッショナブルな/オ ーソドックスな, 洗練された/やぼったい, 上品な /下品な, 若々しい/大人っぽい, フォーマルな/ カジュアルな の10対の形容詞を選定し, 非常に, かなり, やや, どちらであない, やや, かなり, 非 常にの 7 段階評定の尺度とした4).

\section{3 調查}

1996年 7 月に近畿に在住の女子短大生154名を対 象に実施した。 まず, 無背景の服装 7 種類を提示し 


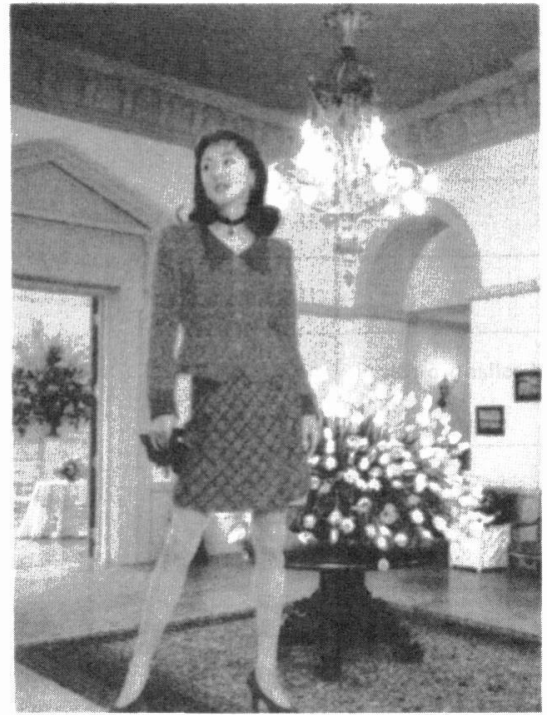

Fig. 2 Example of a Super-imposed Image

て評定させ，次に背景 A（街中）と 7 種類の服装そ れぞれとの合成画像, 続いて背景 B (野外), 背景 C （室内）の順に提示して評定させた.

\section{4 分析}

各段階評定に 1 7 の得点を与え, これらの形容 詞について提示試料ごとに平均值を求め, 服装ごと にイメージプロフィールを描いてその服装のイメー ジを明らかにした ${ }^{5}$. 形容詞10対の各尺度間の相関 係数を求めてこれらの関連性も検討した. 続いてイ メージの要因について因子分析を行い，バリマック 又回転を施して因子構造を求めた. 次に第 1 因子, 第 2 因子の評価に及ぼす服装と背景の影響を二元配 置分散分析によって検討した，さらに第 1 因子を横 軸に，第 2 因子を縦軸にとり，その次元上に無背景 と各背景の服装の評定平均值を服装別にプロットし て, 同じ服装が背景が異なることによって服装評価 がどのように変化するかを検討した。 なお統計処理 には統計解析パッケージ SPSS を使用した.

\section{3. 結果および考察}

\section{1 評定尺度間の関連性}

各尺度間の相関係数を求めた結果, 派手 / 地味 と, にぎやか/落ち着いたの相関係数は0.8213で一 番高い相関を示し, 以下大胆 / 瀻細, 個性的 / 平 凡, ファッショナブル / オーソドックスの各尺度間
で高い相関が見られ， 5 対の尺度で 1 つのまとまり を見た. また上品/下品と, 洗練 / やぼったいの相 関係数は0.6369で，すっきり/ごてごてとの尺度間 でも相関が見られ，この 3 対の尺度もまとまってお り，2つのグループに分かれた. すべて $1 \%$ 水準で有 意性が認められた。

相関係数から尺度が派手，大胆，にぎやか，個性 的の力量性尺度と上品, 洗練, すっきりの評価性尺 度に 2 分された。

\section{2 服装評価の主要因子}

\section{2 .1 服装を評価する因子の抽出}

3 種類の異なる背景を持つ服装を評価する因子構 造を求めるために, 10 対の形容詞を变数に評定平均 値を求めて因子分析を行った ${ }^{677)}$. 因子の抽出基準は 固有值 1 以上とし, その結果 3 因子が抽出された. さらに主要因子として第 1 因子と第 2 因子を用いて 再度分析し，バリマックス回転を施した結果を表 2 に示す．第 1 因子は「派手な」、「にぎやかな」「「フ アッショナブルな」,「個性的な」,「大胆な」の力量 性の因子が高い負荷量を示した. 寄与率は $53.2 \%$ で あった．第 2 因子は「洗練された」，「上品な」、「す っきりした」の評価性の因子が高い負荷量を示し寄 与率は $19.7 \%$ で, 累積寄与率は $72.9 \%$ あったた.

これにより，第 1 因子は「派手」を意味内容とす る因子であり，第 2 因子は「洗練された」を意味す る内容の因子であると解釈した。

\section{2 .2 服装評価の各因子に及ぼす服装および背 景の影響}

服装評価に及ぼす服装および背景の影響の有意性 を調べるために, 要因である 3 種類の背景と 7 種類 の服装を独立変数として, 各因子の評定平均値を各

Table 2 Principal Factors in Clothing Evaluation

\begin{tabular}{|c|c|c|}
\hline $\begin{array}{l}\text { Factors } \\
\text { (Contribution \%) }\end{array}$ & Scale & $\begin{array}{l}\text { Factor } \\
\text { loading }\end{array}$ \\
\hline $\begin{array}{l}\text { 1.Showy } \\
\qquad(53.2)\end{array}$ & $\begin{array}{l}\text { Showy - Conservative } \\
\text { Lively - Calm } \\
\text { Fashionable - Orthodox } \\
\text { Individualitic - Commonplace } \\
\text { Bold - Sensitive }\end{array}$ & $\begin{array}{l}.814 \\
.779 \\
.750 \\
.744 \\
.714\end{array}$ \\
\hline $\begin{array}{l}\text { 2. Sophisticate } \\
\qquad(19.7)\end{array}$ & $\begin{array}{l}\text { Sophisticate - Tasteless } \\
\text { Classy - Vulgar } \\
\text { Simple - Fussy }\end{array}$ & $\begin{array}{l}.862 \\
.764 \\
.711\end{array}$ \\
\hline
\end{tabular}


Table 3 Influence of Type of Outfit and Back-

Showy ground on Clothing Evalvation

\begin{tabular}{l|r|r|r|r|r}
\hline Source of Variation & \multicolumn{1}{|c|}{$\begin{array}{l}\text { Sun of } \\
\text { Squares }\end{array}$} & D F & \multicolumn{1}{c|}{$\begin{array}{l}\text { Mean } \\
\text { Square }\end{array}$} & \multicolumn{1}{c}{$\mathrm{F}$} & \multicolumn{1}{c}{$\begin{array}{l}\text { Signif } \\
\text { of } \mathrm{F}\end{array}$} \\
\hline Background & 1800.9 & 3 & 600.3 & 40.1 & $.00 * *$ \\
\hline Outfit & 103959.9 & 6 & 17326.6 & 1158.2 & $.000^{* * *}$ \\
\hline Background $\times$ Outfit & 1612.3 & 18 & 89.6 & 6.0 & $.000^{* * *}$ \\
\hline
\end{tabular}

Sophisticated

\begin{tabular}{l|r|r|r|r|r}
\hline Source of Variation & $\begin{array}{l}\text { Sun of } \\
\text { Squares }\end{array}$ & D F & \multicolumn{1}{|l|}{$\begin{array}{l}\text { Mean } \\
\text { Square }\end{array}$} & \multicolumn{1}{c}{ F } & \multicolumn{1}{c}{$\begin{array}{l}\text { Signif } \\
\text { of F }\end{array}$} \\
\hline Background & 644.1 & 3 & 221.4 & 26.4 & $.00 * *$ \\
\hline Outfit & 19485.9 & 6 & 3247.7 & 387.9 & $.000^{* * *}$ \\
\hline Background $\times$ Outfit & 3395.9 & 18 & 188.6 & 22.5 & $.000^{* * *}$ \\
\hline
\end{tabular}

服装および各背景ごとに加算して求めた平均値を用 いて二元配置分散分析を行った。 その結果を表 3 に 示す.

第 1 因子の「派手」の因子では,「背景」「服装」 の主効果, 「背景」 $\times 「$ 服装」の交互作用による効果 はいずれす $1 \%$ 水準で有意性が認められた。第 2 因 子の「洗練」の因子でも「背景」「服装」の主効果, 「背景」メ「服装」の交互作用による効果はいずれも 1\%水準で有意性が認められた。この結果は服装の 評価には場面となる背景が大きく関与していること が確認された。

\section{3 服装評価の 2 因子から構成される平面に 評定平均值をプロット}

続いて 7 種類の服装の評価で抽出された 2 つの因 子軸を座標とする平面上に，第 1 因子の「派手」と 第 2 因子の「洗練」を背景別に評定平均値を求め, 服装ごとにプロットしたのが図 3 である.

7 種類の服装のうち服装 $3,4,6$ は「派手」/「地 味」の軸上で「派手」側に, 服装 $1,2,5,7$ は「地 味」側で「洗練」の領域内に附置された. 次に無背 景の服装 D を基準にして 3 種類の背景を伴うこと により, 服装評価がどのように変化したかをみてみ
ると,

服装 1 は，無背景では 7 種類の服装の中では一番 やや「地味」だが,「洗練された」服装と評価されて いたのが場面となる背景が「街中」と「野外」にな ると「地味」さと「洗練」から遠ざかる傾向を示し， 「室内」では少し「洗練」の方向へ変化した。

服装 2 は，無背景では服装 1 ほぞ「地味」であな く「洗練」さむ低く, 特徵の弱い服装と評価され, 背景による影響む小さい。

服装 3 は，無背景ではやや「派手」でやぼったい 服装と評価された。「野外」を背景にしたときは「や ぼったい」の方へさらに大きく変化し, 背景の影響 が大きく表れた。「室内」あ「街中」あ影響は小さい が「やぼったい」の方へ変化した。この服装に関し ては $\mathrm{A} ， \mathrm{~B} ， \mathrm{C}$ のどの背景にあ適さない服装である ことがわかった。

服装 4 は, 無背景では 7 種類の服装の中では最む 派手でやぼったさのある服装だと評価された。赤地 に黄色の柄物という原色の配色からこのような評価 になったと思われるが,「室内」を背景にすると「洗 練」の領域にまで非常に大きく評価が変化し，この 服装は「室内」を背景にしたときが最も洗練された 服装として評価された。 反面「野外」ではさらに「ゃ 


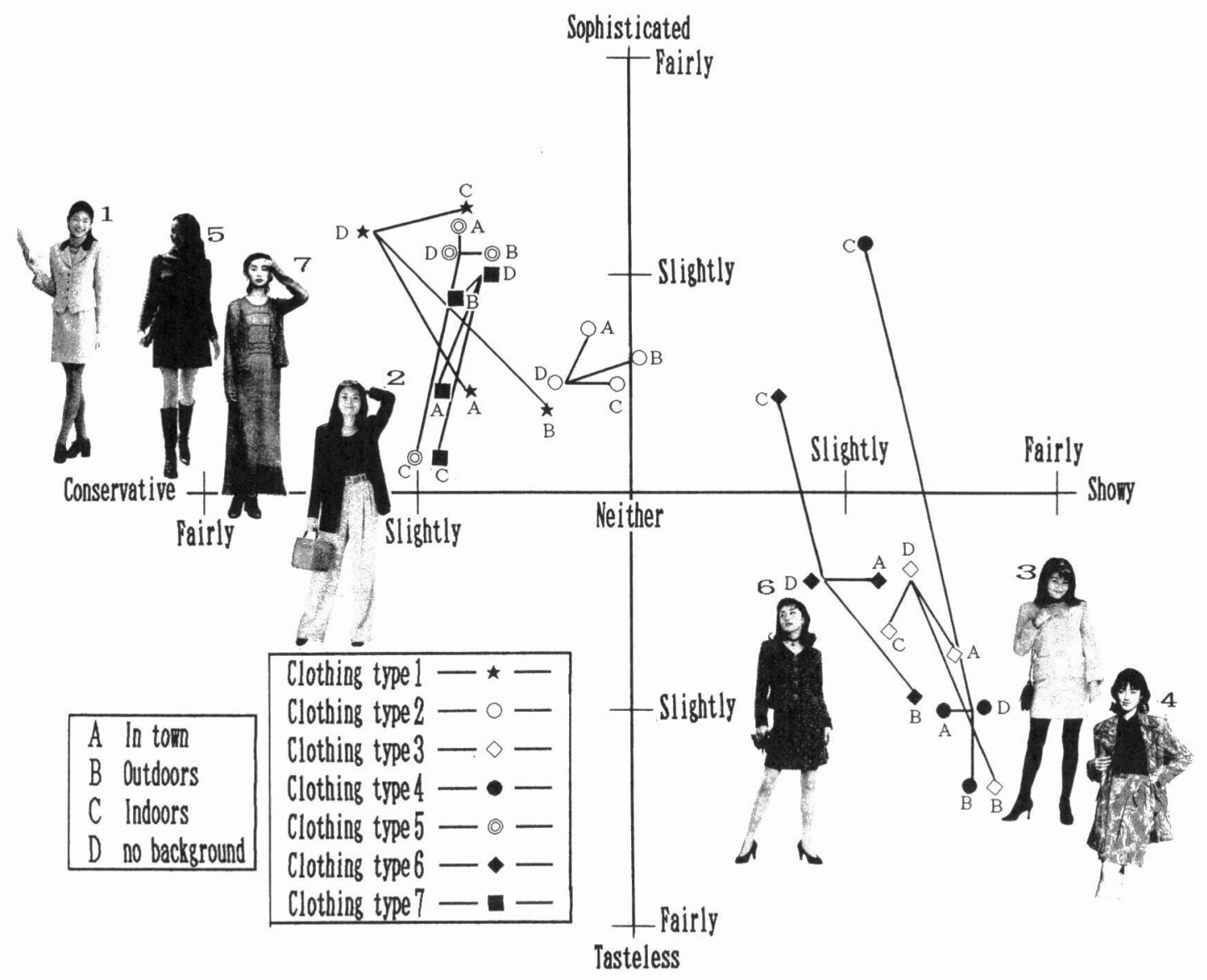

Fig. 3 Evaluation Averages for Each Clothing Background Environment

ぼったい」の方へ変化し,「街中」ではほとんど変化 は認められなかった。この服装は「洗練」/「やぼっ たい」の軸だけで背景の影響が顕著に表れた.

服装 5 は, 無背景ではやや洗練されてはいるが地 味な服装だと評価され,「街中」「野外」を背景にし てあ小さな変化しかみられなかったが「室内」での 服装となると「やぼったい」の方へ大きく評価が変 化し，この服装もまた「洗練」/「やぼったい」の軸 での影響が表れた。

服装 6 は, 無背景ではやや派手でやぼったさむあ る服装だと評価されたが「室内」では派手さが弱ま り,「洗練」の領域にまで大きく変化したのが特徴で ある。「街中」を背景にすると「派手」な方へ少しだ けの変化であるが「野外」を背景にすると「派手」 で「やぼったい」の方へ大きく変化した．この服装 あ背景によって「洗練」/「やぼったい」に影響を受 けている.
服装 7 は, 無背景の服装はやや地味ではあるが洗 練された服装だと評価されたが,「街中」「「野外」, 「室内」といずれも「やぼったい」の方への動きをし ているのが特徴である. 服装 3 と同様に, 無背景の 服装の評価が背景を伴った場合よりあ好意的な評価 を得ており,この 3 種類の背景には適さない服装で あったと言える.

\section{4. 結 論}

本研究の目的は, 服装の評価は衣服の特性と着用 場面および衣服の特性と着用場面の相互作用が影響 を及ぼしているであろうとの仮説のもとに， 7 種類 の服装に 3 種類の背景をコンピュータグラフィック スを用いて得られた合成画像の提示試料によって測 定し, 分析して得られた結果は次の通りである.

(1) 選定された10対の形容詞を変数として因子分 析をしたところ、「派手」を意味する因子と「洗練」 
を意味する因子が第 1 因子と第 2 因子として抽出さ れた.

（2）服装評価の各因子に及ぼす服装および背景の 影響の有意性を調べるために 7 種類の服装と 3 種類 の背景について二元配置分散分析を行ったところ, 背景之服装の主効果, 交互作用は「派手」の因子と 「洗練」の因子，いずれす $1 \%$ 水準で有意性が認めら れ，背景が服装の評価に影響を及ぼしていることが 確認された.

（3）第 1 因子の派手 / 地味を横軸に, 第 2 因子の 洗練された/やぼったいを縦軸にとった平面に評 定平均值をプロットした結果, 背景によって各服装 の評定值に差異が認められたが, 背景が変化しても 比較的評定値の動きに差異の少ないものああり, 服 装によって影響の程度に差のあることがわかった。

（4）服装評価因子の，派手 / 地味の軸は服装を判 別するのに大きく影響を与える軸であることがわか った。 結果的に赤, 黄, ピンクの色みスーツが派手 側に, ベージュ,グレー, うす紫の服装が地味側に 附置された。色彩による影響す要因の 1 つであると
思われる.

（5）服装評価因子の洗練 / やぼったいの軸は提 示する服装の背景の違いによって大きな影響を与え ている評価性の軸であることが明らかになった。

本研究を行うに当たり，ご指導いただきました鳴 門教育大学の藤原康晴教授に深く感謝します.

なお本研究の概要は，1996年第49回日本織維機械 学会年次大会で発表した.

\section{参考文献}

1）磯井佳子 ; 織維工学, 50, P160 P165（1997）

2）山本純子, 加藤雪枝 ; 織消誌， $31 ， 5$, PP. 57 62（1990）

3）日本織維機械学会 被服心理学研究分科会編; “被服心理 学”, P. 206, 日本織維機械学会 (1987)

4）日本織維機械学会 被服心理学研究分科会編; “被服心理 学演習ノート”, P. 34, 日本織維機械学会 (1994)

5）東 洋, 大山 正他; “心理用語の基礎知識”, P. 522, P. 523 有斐閣ブックス627.（1993）

6）岩下豊彦；“SD 法によるイメージ測定”，P. 64, 川島書店 (1992)

7）古谷野 亘; “多変量解析ガイド”， P. 126, 川島書店 (1988) 